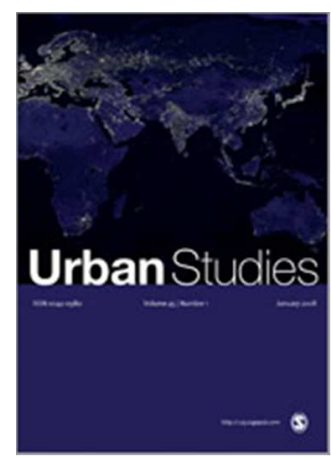

\title{
Beyond the 'post-industrial' city: valuing and planning for industry in London
}

\begin{tabular}{|c|c|}
\hline Journal: & Urban Studies \\
\hline Manuscript ID & CUS-100-16-02.R1 \\
\hline Manuscript Type: & Policy Review \\
\hline $\begin{array}{r}<\text { b }>\text { Discipline: Please select a } \\
\text { keyword from the following list } \\
\text { that best describes the } \\
\text { discipline used in your paper.: }\end{array}$ & Planning \\
\hline $\begin{array}{r}\text { World Region: Please select } \\
\text { the region(s) that best reflect } \\
\text { the focus of your paper. } \\
\text { Names of individual countries, } \\
\text { cities \& economic groupings } \\
\text { should appear in the title } \\
\text { where appropriate.: }\end{array}$ & Western Europe \\
\hline $\begin{array}{l}\text { Major Topic: Please identify up } \\
\text { to two topics that best identify } \\
\text { the subject of your article.: }\end{array}$ & Built environment, Economic development \\
\hline $\begin{array}{r}\text { Please supply a further } 5 \\
\text { relevant keywords in the fields } \\
\text { below:: }\end{array}$ & Manufacturing, Planning, Land use, Urban policy, Industry \\
\hline
\end{tabular}

\section{SCHOLARONE $^{\text {Mx }}$ \\ Manuscripts}


Title: Beyond the post-industrial city: valuing and planning for industry in London.

\begin{abstract}
This paper examines the challenges that planners face if industry is to survive and thrive in a growing 'postindustrial' city. It examines London, where the difference between the value of land for residential and industrial use, and the pressure to address the housing crisis, is leading to the rapid loss of industrial land and premises. The paper first explores the role of industry in a high-value city such as London, arguing that trends in manufacturing in advanced economies are increasing the benefit for firms of an urban location, whilst at the same time, cities continue to need industry if they are to be economically and socially resilient, sustainable and vibrant. The paper then explores current approaches to planning for industry in London, identifying impacts of a policy framework that anticipates and plans for its decline. Finally, it focuses on the question of how to plan for a productive and inclusive city: we explore the arguments in favour of integrating industry into the urban fabric as well as the benefits of separating land uses and retaining employment land designations, and reveal how urbanists are divided. We argue that if London is to continue to prosper, and meet the needs of all Londoners, then we need to strategically and proactively plan for industry in the city, to experiment with innovative ways of integrating it with other city uses, whilst protecting land for industry, where required. We put forward a critical research agenda to effectively meet this challenge in the future.
\end{abstract}

\title{
Keywords
}

Industry, manufacturing, planning, urban policy, land use

\section{Introduction}

The fate of cities across north America and western Europe in the transition from industrial to so-called 'postindustrial' economies has been diverse. Whereas some cities and regions have struggled to rebuild their economies, others - such as London - have seen a rise in jobs in the financial and business services and creative industries, which has been equally as dramatic as the loss of jobs in manufacturing and industry (Clark, 2002; Pratt, 1994, 1997; Sassen, 2001). Measured in terms of GVA (Gross Value Added), London is now ranked one of the top five most successful cities in the world, achieved through "a shift to higher skilled, higher 
productivity employment" (London First, 2015: 16). This paper acknowledges the significance of this shift for the economy, wages, organisation of land uses and so on. However, we concur with Cohen and Zysman (1987) that the notion of the post-industrial economy is misleading, suggesting a split from the past that does not adequately acknowledge the role of global cities such as London or New York in global production, the interconnectedness of economies or the dependence of the financial and business services sector on various industrial activities to thrive and function.

There are two strongly voiced concerns about London currently. The first is around its global competitive position, which shows that the city's economic growth has slowed since the 2008 recession; it is no longer ahead of its rivals, "but has now fallen back to being one of the pack" (London First, 2015: 18). This is leading to a strong sense that London cannot take its growth for granted, and that it needs to rebalance the economy and build its economic resilience through supporting growth in a broader range of sectors, including manufacturing and industry. This led to the Chancellor, George Osborne, calling for a "march of the makers" in his budget speech of 2011 (HC Debate, 2011). The second is a concern that, as the city's population grows ${ }^{i}$ and residential property prices escalate, "the city is eating itself" interesting and special, as well as what makes the city work, including well occupied and functioning employment space, suitable for both new and traditional industries, as well as start-ups and small and medium sized enterprises (SMEs) that seek more flexible, affordable space (JSEP, 2015). We suggest in this paper that there needs to be a better understanding of the links between these two concerns. The Chancellor's 'march of the makers' has so far not materialised, with manufacturing's share of GDP stagnating at around 10\% (Chang, 2016). Part of this failure, we suggest, is a lack of political commitment and investment, as well as a failure to address the problems of accommodation.

In London, industrial displacement is being fuelled primarily by housing development in the city, where the average ratio of residential to industrial land values is 3.2 to 1 across London and 7.6 to 1 in the centre resulting in significant market pressure to release industrial land for housing (AECOM, 2016: Figure 4.6). In North American cities, such as Toronto (Catungal et al, 2009), New York (Indergaard, 2009) and San Francisco (Hutton, 2009), industrial displacement through commercial gentrification is of greater concern, whereby digitally based industries - that use space more intensively, are more productive and therefore can afford higher rents - are pushing out lower-value commercial activities that use less digital technology. In San 
Francisco, the displacement by tech tenants is hitting the headlines (McDermid, 2016). Although the tech industry in London's Old Street has similarly fuelled office rents, which have risen by $87 \%$ in the last six years (Savills, 2016), and there are concerns that this is undermining the area's start-up ecosystem (Charisi, 2014), the bigger worry across London is displacement of industrial (and other lower-value land uses) by the rampant residential market (Moore, 2015).

This paper focuses on the specific problem in London, but its conclusions are relevant to other cities that are experiencing industrial displacement by higher-value uses; no matter what those uses are. We argue that the prevailing approach of London's 'managed decline' industrial land use policy and the exclusive priority placed on housing does not recognise either the contribution of traditional manufacturing and industry to the city, nor does it allow for London to capitalise on future employment growth in new urban manufacturing, which relies more extensively on digital processes. As yet, there is no agreement on how important (or not) it is to retain and promote industry in the city. Even if there were a greater consensus, there is a divergence of opinion on how we should achieve it in spatial terms. The paper is structured to consider these issues in turn. The first section tackles the assumption that manufacturing and industry is better accommodated in parts of the country (or world) where both land and labour costs are cheaper. It considers why a high-value city such as London still needs such commercial activities and, in turn, why they might need, or thrive better in, such a city. The second section then explores how we best go about 'planning' for industry in the contemporary city, where there are also other pressures on land use. Here, divisions of opinion are exposed on the merits of separating industry from other land uses, versus the benefits of a mixed city. The third section concludes and reflects on implications for future urban policy.

\section{Why industry in London?}

There is a widely held perception that manufacturing and industry are in terminal decline in the UK, and certainly in London. The mainstream opinion, expressed by the influential business membership organisation, London First (2015: 22) is:

that large-scale manufacturing will not return to high-cost cities like London, even if re-shoring brings some manufacturing employment back to advanced economies as a whole. Changing technology may 
drive some pockets of growth, for example in close-to-market creation of prototypes through 3D printing. However, these pockets are unlikely to generate significant employment; particularly since the economic reasons to locate outside high-cost locations will become more compelling if employment grows. (London First, 2015: 22)

The trend is generally referred to as deindustrialisation, whereby mass production in large factories moves away from high value locations in inner cities to lower value land on the edge of cities, in other parts of the country, or in emerging economies; in short, places where both land and labour are cheaper. Such trends have broadly followed the logic of bid rent theory ${ }^{\mathrm{iii}}$, whereby the location of land uses and their values are determined by a competitive bidding process, where those uses that benefit most from being located in the centre will outbid other uses.

It is this trend of deindustrialisation that underpins the Greater London Authority's employment projections that there will be an $88 \%$ loss of manufacturing jobs from 129,000 in 2011 to just 15,500 in 2050, and that other industrial jobs will also drop significantly; $73 \%$ in primary and utilities, $52 \%$ in wholesale and $38 \%$ in transportation and storage ${ }^{\mathrm{iv}}$. These projections are based on extrapolating past employment trends; but there are already indications that this trajectory will not simply continue - latest figures show that between 2010 and 2015 employment in manufacturing in London has increased slightly (London Datastore, 2015) and industrial employment generally has risen by 4.4\% (AECOM, 2015: Table 3.6). The GLA's interim employment projections (GLA Economics, 2015) treat this as a 'blip', but this is debated. A report by PwC (2009) argues that focusing only on employment and manufacturing's contribution to GDP is misleading. The UK picture in terms of employment is that 1 in 10 jobs were in manufacturing in 2008, compared to 1 in 4 in 1980, but jobs have been lost as productivity in the sector has increased. Manufacturing has been in 'relative' rather than absolute decline, in other words manufacturing's share of the total economy is in decline, but this is because services have grown more quickly than manufacturing. Advances in technology mean that, although jobs have been lost, there has been a steady rise in productivity in manufacturing, so that its outputs (measured by GVA) have risen. This resonates with Cohen and Zysman's (1987) warning that we should not confuse a shift of labour out of manufacturing with a shift out of manufacturing production in general; the former can occur even without any offshoring of the latter. 
We need a better insight into the nature of the manufacturing that has remained and why it has done so. As Curran (2007: 1429) argues in the context of New York: "Those businesses that could, left the city long ago; those that remain are the ones that need to be there or have a business advantage because of their urban location". There are a range of broader industrial businesses and activities that depend on the businesses and residents of the city for custom, and without which the city would cease to operate effectively or flourish,

We also need to understand the potential impact and spatial implications of the argument that we are on the brink of a 'new industrial revolution', which is only just gathering force and that advanced industrialized nations are well placed to take advantage of this (Anderson, 2012; Marsh, 2012). Chris Anderson argues that the two decades of innovation that we have seen, based on the Web, is about to be applied to the real world. Making things has gone digital, and once an industry goes digital and can be done on regular computers, they can be done by anyone: "Would-be entrepreneurs and inventors are no longer at the mercy of large companies to manufacture their ideas" (2012: 18). This transition is what lies behind the enthusiasm for a 'maker movement' (Hatch, 2014) and the rapid growth of 'makerspaces' around the world. This section considers first why industrial businesses (both old and new) might need, or thrive better in, a high-value city such as London, and second why these cities still need manufacturing and industry.

\subsection{The benefits to industry of being in the city}

In aggregate, we know that service businesses benefit much more from agglomeration economies (or clustering) than manufacturing businesses, but there are exceptions to the rule such as high-tech manufacturing (Cheshire et al, 2014; Graham, 2007). In addition, there are still many individual manufacturing businesses that benefit from an urban location, either because they depend on proximity to other businesses, proximity to their markets or access to skilled (or cheap) labour. There are also reasons why trends in urban manufacturing are pulling small, innovative manufacturing businesses to cities.

Industry has traditionally sought a city location to be close to its markets. As documented by Peter Hall (1969), London was historically home to industries at the end of the production chain: clothing manufacturing rather than textiles; furniture, rather than woodworking; printing rather than paper production; and jewellery and 
watchmaking rather than metal manufacture. For these industries, London offered a large pool of relatively wealthy customers, as well as access to national and international markets. These production processes were also 'vertically disintegrated' i.e. separated into many specialist processes, using subcontracting for different aspects of the production process. This meant that they were hugely dependent on each other and benefited from external or agglomeration economies. The increased use of road-based deliveries and the decreased cost of transportation has meant that many industries no longer need to be cheek by jowl with their markets, and mass producers can co-locate many different specialist processes. However this is not always the case. Some manufacturing businesses still rely on proximity to both other businesses in the supply and co-production chain, and their customers. For example, in Charlton Riverside in southeast London, there is a collection of complementary companies working in lift manufacturing and repair. Here, lift manufacturers and repairers are located next to specialist steel stockholders and electrical fitting suppliers. Working in close symbiosis, these firms can offer a rapid lift repair service to firms in the City and Canary Wharf, as well as to local residential high-rise blocks (JSEP, 2014). This is also an example of where it is becoming harder to classify companies as either manufacturing or service-based. As emphasised by PwC (2009: 7): “[t]he line between manufacturing and services is becoming increasingly blurred as more and more companies are operating in both areas, or bundling goods and services together in customised packages for clients".

Recent trends are also re-emphasising the importance of proximity. First, the rise of niche, bespoke production means that producers need to be close to their markets, to understand and effectively respond to them. Second, as customers become wealthier, they generally become more demanding in terms of speed of delivery and service, and there is also a trend towards integration of manufacturing and retailing, where customers can buy products straight from the site of production. This has been actively planned for in New York's Industry City, facilitated by the flexibility permissible within the Manufacturing Zoning covering the area, which has brought retail onto the site to allow customers to buy products directly from producers and makers (Kimball, 2015). Although this only tells part of the story, argues deMause (2015): the upscaling of commerce on the site has pushed up commercial rents, directly displacing those remaining manufacturers, artists and lower-cost food vendors from the site and neighbouring commercial areas, breaking the link between residents and local jobs, and more generally driving up residential rents and prices in neighbouring Sunset Park 
as the area becomes more desirable. These negative effects have been documented despite the fact that rezoning has not allowed for residential development within the site itself.

Another important benefit of agglomeration is the availability of labour and ability to share equipment and premises. Scott (1982) argues that this is particularly important for businesses in the incubation phase. New, small firms tend to seek out the mutually supportive environment provided by a concentration of other similar firms, with similar needs. As firms grow, they become more self-sufficient and less dependent on other firms or the availability of such externalities, and can take advantage of lower land costs in more peripheral locations. This has been the trend in mass manufacturing, where the processes of design and production are often separated. However, in mature economies, where there is a growth of smaller-run manufacturing for niche markets, it is harder to separate from the manufacturing process, since design and manufacturing choices are closely intertwined. As the CEO of the design software giant, Autodesk, explains:

During the period where people tried to exploit offshoring and outsourcing, manufacturing and design got divorced from each other. Now companies are realizing that if you get too divorced from making the product, you don't understand how to improve it. (quoted in Leber, 2013).

This highlights the problem of rhetorically separating 'knowledge-based' and 'productive' economies, as if knowledge, ideas and innovation are not central to manufacturing. Spatially, if manufacturing in mature economies is shifting from larger to smaller companies, as well as relying on greater innovation and proximity to the design process, it follows that future urban manufacturing will benefit more from the agglomeration economies provided by the inner city than in the past. In other words, the 'new economic geography' put forward by Paul Krugman and colleagues (Krugman, 1991; Fujita et al, 1999) as an explanation for the tendency of industries of the information age to cluster in cities despite advances in telecommunications, needs to be expanded more explicitly to accommodate the trends we are witnessing in manufacturing. In new urban manufacturing, there is a closer symbiosis between production and design, research and development, which again relies on access to skilled labour. In London, there has always been ready access to both skilled and cheap labour, due to it being a first point of call for most immigrants into the country (Hall, 1962). Scott (1982) argues that throughout history, there has been a tendency for labour-intensive firms to seek central locations (with access to the greatest 'pool' of labour), and for capital-intensive firms (those who 
depend more on larger premises or machinery) to seek peripheral locations, where land is cheaper. With improvements in technology, we have seen over the course of history, a displacement of labour (people) by capital (machinery) in manufacturing. Thus, over time, we have increasingly seen firms disperse or decentralize. However, the nature of labour in manufacturing is changing:

The manufacturing of the past was characterised by long production runs and repetitive manual labour. It was used to make goods that varied little between one day and the next. The focus in the industries of the future will be on fast changing products, created to high specifications, often through mixing a range of technologies, from electronics to biotech. Next generation manufacturing will be tailored to individual requirements and fabricated in short runs. (Marsh, 2015)

This will require more skilled labour, proximity to centres of research and development, and other technology sectors. This all suggests that, for industries of the future, it will be increasingly important to be near other businesses, to be close to markets, and to have access to skilled labour - all of which are more accessible in cities than their peripheries. This suggests that we are likely to see continued agglomeration in the materially productive sectors of the economy as well as in service and information-driven industries, hitherto well documented. In short, for industries of the future, cities will be more important.

\subsection{Cities need industry}

Conversely, cities also need industry. The most obvious reason is because there are industries that are essential to keep the city functioning, to provide goods and services to its businesses and residents, to deal with its waste, to provide materials for its construction, and so on. A consultants' study of industrial premises in London remarks:

\footnotetext{
Just consider the diversity of services and products consumed by the average office building: catering; cleaning; furniture; maintenance and fit out; office equipment and supplies; print and copy; security; waste disposal and many others...Much of this support activity is located away from the central area, often clustered around the central area and in outer London... Often the activity is "low key", but is vital to the efficient functioning of the city and in supporting its global role (Harris, 2013: 1).
} 
In San Francisco, these businesses have been given the name 'back street businesses', referring to "an industry that often exists behind the scenes, but provides thousands of well-paying jobs to local residents and essential goods and services to Main Street businesses, local residents and the larger economy." (BBAB, 2007: 6) Furthermore, the need for such back street businesses only increases as these cities' residential and business populations grow and become increasingly wealthy, with changing lifestyles that demand the delivery of 'just-in-time' goods and services facilitated by the touch of an app button. An employment study for a central London borough (Roger Tym and Partners, 2011a) identifies a number of examples of such businesses providing goods and services with a short 'shelf life', including florists serving small retail outlets in stations, Asian fast food kitchens, and taxi firm 'Addison Lee' which needs a central administration and vehicle garaging centre, to enable quick dispatch of vehicles to respond to market demand. A central location for such businesses is important as they are required to guarantee timed deliveries to customers or their own retail outlets.

The construction industry, which has supported London's property boom, depends almost entirely on industrial land available within London, particularly the manufacture and supply of construction materials, but also related services such as plumbers' merchants, scaffolders, trade wholesalers etc. Facilities like aggregate yards may be unattractive neighbours for nearby residents, but nevertheless form part of the essential infrastructure for London's construction industry.

Retaining manufacturing and industry helps the city to be more diverse and therefore more economically and socially resilient. It has long been known that diverse economies, i.e. those that do not rely on a narrow range of economic sectors, are more resilient (Chinitz, 1961). London has grown on a very diverse economic base. Peter Hall observed in the mid $20^{\text {th }}$ Century that "the capital was clearly the most important single seat of manufacturing industry in the country" (1961: 23) but this was often not recognised since the city was highly diversified and not known for any specialised product. Most innovations and new firm start ups take place in large diversified cities (Duranton and Puga, 2000; Feldman and Audrescht, 1999; Jacobs, 1960). In London, there is now a concern that the city has become overly reliant on the financial and business services sector, such that one of the three stated goals of London 2036 (London First, 2015: 4) is to increase London's diversity and resilience, promoting strong performance across more of the economy, with no single sector contributing more than $40 \%$ of GVA or jobs growth. Promoting resilience also requires ensuring a balance between imports 
and exports. At present, the UK imports more goods than it exports, but it exports more services. In 2012, the Chancellor George Osborne set a target to double UK exports to $f 1$ trillion by 2020. London has a long history as a trading centre; its demography and international reach means it is well placed to lead the UK's exports drive (Theseira, 2014). However, its potential is limited by availability of suitable premises and land for new manufacturing activity (Marsh, 2015). Solving this issue would support the economy, but it would also promote social equity in the city, by providing a greater range of jobs, both skilled and unskilled, but with the potential for higher wages, job progression and satisfaction than the service industry (see Krugman \& Lawrence, 1993, for a good discussion of the relationship between economic sectors and wages). This might be particularly important in London, which has a relatively low employment rate given its very high wages, and is an exception to the general rule that employment rates and wages are positively correlated (Cheshire et al, 2014; 20). This is consistent with the observation that the so-called 'knowledge economy' has not solved the problems of cities; the gap between rich and poor has got worse and long-term unemployment remains a major issue (Madanipour, 2013). This challenge is acknowledged by policy makers in London. Camden's Core Strategy (LB Camden, 2010: para 8.12) suggests that “[p]remises suitable for industrial, manufacturing and warehousing businesses provide jobs for people who would otherwise be at high risk of being unemployed or workless".

Retaining industry in cities is also fundamental to promoting sustainability. The imperative for London to sustainably deal with its waste means that there is a demand for sites to accommodate this essential element of London's infrastructure. For example, Powerday building waste recycling centre occupies a site in Park Royal, and makes use of rail and canal infrastructure to transport waste thus reducing lorry movements (GLA, 2014: 72). Similarly, work by Cass Cities ${ }^{v}$ has shown that recyclate production is increasing in London and is becoming a significant element of manufacturing. For example, the Dagenham gasification plant will turn 180,000 tonnes of waste each year into 19MW of energy, while producing metal, aggregate and glass recyclates. Newer businesses, such as Closed Loop who produce food-grade plastic recyclate out of plastic bottles, wanted to be in London because of its stream of waste.

As well as increasing opportunities in cities for green industries, the accommodation of industry in the city reduces travel distances between production, services and markets, which is particularly important in light of 
the growth of 'just in time' goods and services, and crucial if we are to reduce congestion and carbon emissions from (mostly diesel) vehicles used by such companies.

A final argument - currently underdeveloped - is that industry makes for a more interesting and vibrant city. As stated in the urban lifestyle magazine, Monocle (Tuck, 2009):

City streets need to be pleasant places to live but also home to small businesses, craft makers and even the odd car mechanic. They might be unsightly, noisy and lower the tone of the street but they are what make a neighbourhood thrive. And anyway, too much peace and quiet can be bad for you.

Such ideas underpinned arguments made in the 1960 s by Jane Jacobs in her seminal book, The Death and Life of Great American Cities, later an inspiration for Sharon Zukin's (2010) Naked City: The Death and Life of Authentic Urban Places. Jacobs (1961) argued: "City diversity itself permits and stimulates more diversity" (p.145). The same conditions that create diverse commerce, she claims, also promote other types of city variety; diverse cultural opportunities and "a variety in its population" (p.148). Such ideas underpin the enthusiasm for mixing land uses in cities, which is discussed in the following section, but there is by no means a consensus about how we should effectively incorporate production into our cities.

\section{Planning the productive city}

The evidence suggests that if London is to continue to prosper, whilst meeting the needs of all Londoners, then we need to think more carefully about how to plan for a productive city. But how should we do it? Before going on to discuss future options, it is helpful to explain how London currently plans and what the key challenges are.

\subsection{Current approaches to planning for industry in London}

There is almost 7,000 hectares of industrial land remaining in Greater London (AECOM, 2016), representing about $4 \%$ of the total land in the metropolitan area. Industry in London is protected through area-based designations at both the regional and local levels. Strategic Industrial Locations (SIL) afford the highest degree of protection, with losses only allowed as part of a coordinated process of consolidation. Locally Significant Industrial Sites (LSIS) require regular reviews of supply and demand to justify continued protection, and 'Other' 
industrial sites are not protected strategically but managed by borough policies. (GLA, 2015: 160; GLA, 2012:

7). $51 \%$ of London's industrial capacity falls within SIL, $14 \%$ within LSIS and $35 \%$ within 'other' industrial sites, with no policy protection (AECOM, 2016).

The evidence base supporting the London Infrastructure Plan predicts an $88 \%$ loss of manufacturing jobs by 2050, leaving only 15,500 jobs in this sector (GLA Intelligence, 2013). Policy documents refer to the historic structural change in London's economy, moving away from 'traditional manufacturing industries' to the 'service sector' (GLA, 2008: 14). Similarly, the Mayor's Economic Development Strategy (GLA, 2010) presents a potted history of London's economic growth where industry and manufacturing are portrayed as part of London's past. These sentiments are echoed in many consultants' studies, for example one observes that "land use planning designations have lagged behind economic change and consequently too much land has been allocated and protected for industrial use in London" (URS, 2007: 82).

The Mayor's response has been to plan for the 'managed release' of industrial sites by identifying annual targets or benchmarks for each of the 33 London boroughs. However, planning practices - in response to development pressures - are speeding this decline, over and above the benchmarks set out in policy. In the period 2011-2015, London has lost 100 ha of industrial land on average a year, 2.7 times the benchmark in policy (AECOM, 2016), a higher rate of loss compared to the periods 2001-2006 (URS, 2007: 9, 82) and 2006-10 (GLA, 2012: 8). Reasons for losses over the benchmarks were explained through interviews with planning officers from six London boroughs, undertaken as part of a study for the GLA (Roger Tym \& Partners, 2011b: 19):

\footnotetext{
there is very little understanding of strategic employment land issues in development control teams ... most policy officers reckoned that their development control teams had no familiarity with the benchmarks or with the GLA evidence base in general. They might understand the general strategy, but not the detailed benchmarks, rationale or technical detail behind the numbers.
}

The problem is not simply one of bureaucratic inadequacies at the coalface of planning, however. Despite substantial losses of industrial land over and above the targets, annual benchmarks have not been substantially revised and the overall approach of managed decline remains. This is despite an understanding that the official figures underestimate the scale of loss, not taking into developments with planning 
permission, account transactions that take place under the radar, or losses in the pipeline due to policy changes, such as Opportunity Areas and Housing Zones (AECOM, 2016). A strategic choice is being made to sacrifice remaining industry to housing- a strategy that rests on the assumption that jobs in manufacturing and industry will inevitably continue on a downward trajectory, ignoring the possibility that the loss of jobs could have been been accelerated by the inability of companies to secure suitable space in the capital.

At a local level, it is becoming common practice for London boroughs to give more flexible mixed use designations to their locally significant industrial sites. For example, the London Borough of Brent in northwest London has identified one such industrial area (Alperton) as a growth area, which needs to accommodate a proportion of the borough's housing targets over the next 10-15 years. As part of this process, sites that were protected for industrial use are being given a 'mixed use' designation, in order to be able to accommodate housing (LB Brent, 2011). In Lewisham, southeast London, several such sites have been given a designation of Mixed Use Employment Locations (LB Lewisham, 2013), but it is unclear how the Council will secure any significant employment on these sites (Author forthcoming). Many more examples across London could be given. In addition to the sites that were previously protected by policy for industrial use, approximately half of London's industrial capacity falls outside areas that are protected as 'strategic' land (AECOM, 2016) and therefore they are much more vulnerable to redevelopment. In some cases, these are sites that are in local authority ownership, but ripe for disposal. For example, in Camden, there are a significant number of industrial sites and premises in Council ownership that are being sold to fund its Community Investment Programme ${ }^{\mathrm{vi}}$. The fact that local authorities are under pressure to sell off their own industrial sites in order to fund basic community services adds another dimension to the potential scale of loss in the pipeline.

The problem is therefore twofold: a strategic policy approach that continues to support the managed decline of industry and its replacement by housing, together with local planning practices that further undermine remaining industry and serve to accelerate the loss over and above benchmarks set in the London Plan. In this paper, we have argued the case for the importance of a proactive approach to accommodating both traditional and new manufacturing and industry in the city. To achieve this requires political commitment at the highest level, which embraces industry in the city as an integral part of the vision for its future. Achieving 
this political commitment will be a task in itself, but once achieved, there is likely to still be much divergence of opinion on the best way to plan for and accommodate industry into our future cities.

\subsection{How should we accommodate industry in the city? Divergent opinions}

This final section exposes this divergence of opinion on the merits of the separation of industrial land (or 'zoning' in the north American context), revealing that there are different opinions on the benefits for agglomeration, sustainability, diversity and vibrancy, and affordability.

Arguments against planning control and the separation of land uses are most often made on the basis that this interferes with the market-led mechanisms that promote agglomeration (see Heikkla and Hutton, 1986). As Stringer (2014) argues, "industry has moved on, but industrial land has not been allowed to move with it... We need to positively meet the real needs of modern industry, planning more new development in the right places, and letting go of more land in the old places." By constraining employment to designated industrial land, the argument goes, we are undermining the economic potential of our cities. However, due to the susceptibility of industrial uses to displacement by higher-value land uses, a counter argument to this is that we need to protect industrial land if we are to create the conditions for industrial agglomeration to occur at all:

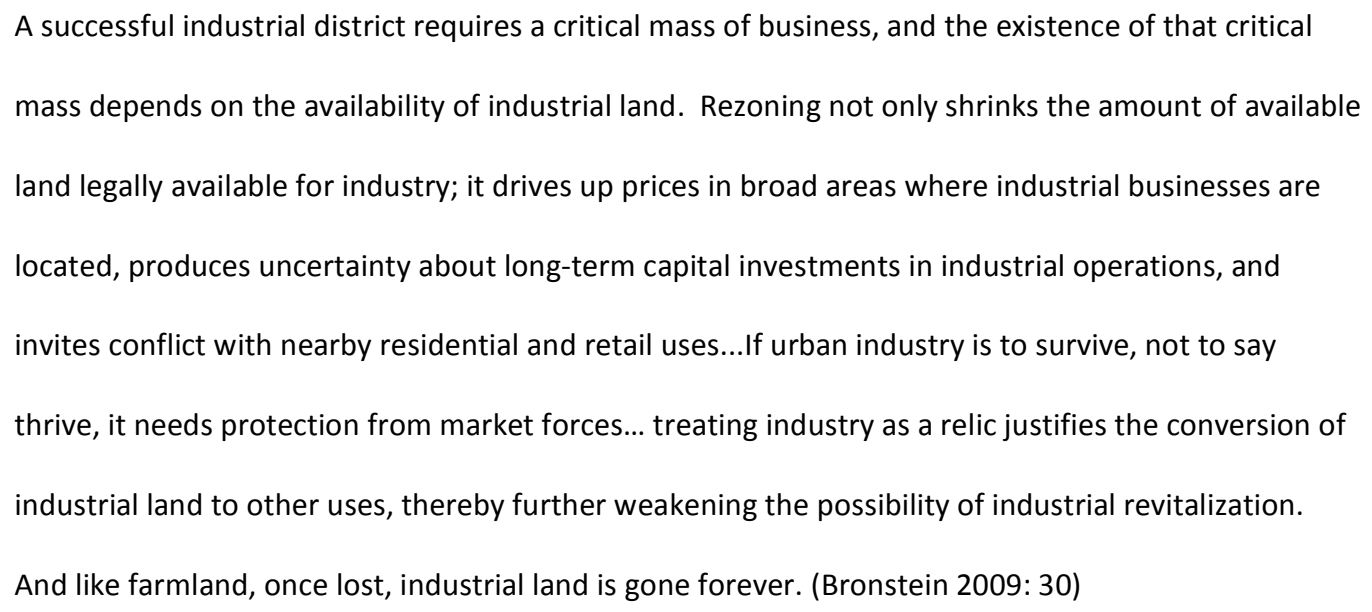

Another argument often put forward by proponents of zoning is that it fosters a greater diversity of the economic and employment base, which is important if a city is to be resilient in future economic downturns (see Heikkla and Hutton, 1986, for a summary of this perspective). Implicit in this discussion is the important function of employment land being to protect lower-value commercial uses from the rising land values of the 
inner city and competition from higher value land uses, in particular housing. Scott (1982) argues that this is considered particularly important to enable new, innovative businesses in the incubation phase to locate in the urban core where they can benefit from a mutually supportive environment being surrounded by similar businesses with similar needs. Positive agglomeration effects include the availability of labour, the ability to share equipment and premises, and proximity to other businesses in the supply and co-production chains. As firms grow and expand, they become more self-sufficient and less dependent on other firms or the availability of such externalities, and can take advantage of lower land costs in more peripheral locations.

This rather suggests that the protection of industrial land is only necessary or useful in the urban core. However, Chapple (2014) has further argued that the availability of industrially-zoned land contributes to the regional economy by providing flexibility, specifically offering a reserve of relatively large sites that can accommodate a range of businesses. She suggests that whereas start-ups (in their very initial phases, as lowoverhead home-based businesses) can locate in residential areas, firms that expand - whether in production, distribution, and repair or information-based services - benefit from the ability to spill into available space in large buildings. Industrial zones facilitate this more effectively than commercial zones, she argues, perhaps because they have more of the 'flex' space that allows firms to grow and shrink readily.

To date, there is no effective mechanism in the UK context to protect industrial land values within a mixed-use area. Rather, there are likely to be knock-on effects of the loss of industrial land to mixed-use. First, new employment floorspace created within mixed-use redevelopment schemes tend to be let at significantly higher prices than the employment floorspace it replaces (Ferm, 2014). Second, the expectation by developers that mixed-use redevelopment can be achieved raises land values across the industrial area and means that new commercial development is less viable (Roger Tym \& Partners, 2011a: 13). Designated employment land provides a 'reservoir' of affordable space, relatively insulated from the high and rising land values associated with mixed use areas.

However, as Heikkla and Hutton (1986) argue, we need to be cautious in assuming that protecting industrial land in the urban core will necessary increase diversification. The loss of diversification in the central core may, in fact, increase diversification in the broader region. Similarly, as Turok (2004) suggests, there are also 'diseconomies of agglomeration', in that agglomeration increases the demand for land, which forces up property prices and rents for all land uses. Therefore, supporting the protection of industrial land in the urban 
core in order to both support agglomeration and protect affordability may not be mutually compatible objectives.

It is also not clear whether a separation of land uses and the protection of industrial land supports or undermines sustainability objectives. On the one hand, mixed-use - whereby a range of different commercial, residential, leisure and community land uses are accommodated together within a building, site or district - is supported by the environmental sustainability agenda of compact cities, following the traditional European model, by the European Commission in the 1990s (CEC, 1990) and there are parallels in the 'new urbanism' and 'smart growth' movement in the US. On the other hand, critics of the smart growth agenda (Bronstein, 2009; Leigh \& Hoelzel, 2012) argue that protecting industrial land is wrongly seen as undermining sustainable land use. On the contrary, sustaining urban industry "fends off urban sprawl" (Bronstein, 2009: 28) caused by outward movement of industry. It also promotes more sustainable transportation between businesses occupying industrial land and the other businesses they serve and interact with.

The broader arguments for mixed use over separation of land uses are often more ideological and aesthetic than driven by a concern for the environment, drawing on arguments considered earlier in this paper around the benefits of diverse commerce for urban vibrancy and authenticity. But the proponents of mixed use are divided in their enthusiasm for retaining industry in the city. On the one hand, there is a perspective that the loss of manufacturing in industrial cities of north America and Europe has eroded any logic behind the continued physical separation of employment land from other city uses and housing, the assumption being that businesses in the new economy (Scott, 2006) no longer seek traditional employment locations, but are more attracted to the mixed-use environments typical of city centres. Promoting more mixed-use also allows employment land to accommodate housing development, and meet the pressure for housing growth. From this perspective, the loss of industry through the redevelopment of industrial land for mixed use redevelopment is unproblematic. On the other hand, there are industry 'enthusiasts' who argue that industry should be much more integrated into the urban fabric (Brearley, 2015; Cotter, 2012; Urban Design Group, 2014). Mark Brearley, Professor at Cass Cities in London, argues: "We need to shout out that a good city has industry, and not hidden away, but embraced, extrovert, noticed. A good city can accommodate its messy as well as its neat" (Brearley, 2015). Along similar lines, the Urban Design Group promotes a concept of the 
"industrious city", which supports bringing more industrious activities into cities and re-appropriating our business parks, driven by a desire to support and celebrate manufacturing activity in cities:

There is an opportunity to move away from the rooted practice to design these sectors out of our towns and cities. Let's make them visible again and stop housing them in anonymous sheds. Let's reappropriate industrial estates and districts through raising the quality of their design and maintenance. As a result, local communities could have a better understanding of how their local economy is formed and develop a sense of ownership. Let's celebrate manufacturing industry again. (Urban Design Group, 2014: 2).

The concept of a future 'industrious city' might well entail overlap of land uses that are often deemed incompatible. But the enthusiasm for reintegration is driven by revolutions in technology, which mean that many industries are cleaner and quieter than they used to be and production no longer entails large factories capable of mass producing goods, but can be accommodated in small and discreet buildings (Marsh, 2015), more easily integrated into a mixed-use environment, with housing and other community uses alongside. However, not all industry and industrial processes fall into this category and arguably it is a long way to go before the commercial market reflects such enthusiasm.

Property agents acting for the industrial sector have argued against 'vertical separation', where business uses are accommodated on the ground floor, with residential uses above. In a report to Camden, a central London borough, consultants Roger Tym \& Partners (2011a: 14) state that although occupiers are generally prepared to compromise on the quality of the building stock and price, they generally do not compromise on key locational features such as proximity to customers, unencumbered access and sufficient distance from residential neighbours to enable 24 hour operation without complaints. They report many new mixed use developments with industrial space on the ground floor that remain un-let and argue that developers tend to pay little attention to the design and specification of the industrial part of the development, treating it as a 'loss-leader' and may even have in mind a future change of use to residential. Navigating a way through differences of opinion both within and between professions is not easy.

This final section has revealed that moving forward on the question of how to plan for a future city, which embraces industry, is not straightforward. There are divergent opinions on the question of separating land 
uses, which go beyond ideological or aesthetic considerations of mixed use development. These include differences in opinion on how to best facilitate agglomeration, and promote sustainable patterns of land use.

\section{Conclusions and policy implications}

This paper has explored the challenge of how to facilitate the provision of adequate land and premises for diverse industrial activities to thrive in our future cities, where the population is also growing. In the first part, we argued that various trends in manufacturing and industry in advanced economies are increasing the benefit for firms of an urban location. These include: a focus on making bespoke, niche products, where proximity to the end consumer and an integration between production and design is more important; an increasing reliance on technology, which requires higher-skilled workers; the growth of small and micro manufacturing firms, which depend more on an urban location; and the blurring between manufacturing and services as we have seen a growth in demand for 'just in time' goods and services and authenticity. Therefore, for many industries of the future, cities will become more, not less important. At the same time, we have argued that cities need industry if they are to be economically and socially resilient, sustainable and vibrant. The first message is therefore that we should be planning for more industry in our cities as we move into the future, and that new producers are likely to be smaller-scale and more urban in their requirements than we have been used to.

The second part of the paper revealed that current approaches to planning for industry in London are resulting in a rapid loss of industrial land and premises, undermining the city's future potential and reinforcing a spiral of decline. On-going loss of premises undermines business confidence and diminishes the critical mass required for businesses to function effectively. Furthermore, it gives strong signals to potential entrepreneurs that London is not a secure place for them. The second message is therefore that stronger strategic direction is required at the regional level - in this case the Mayor of London - to create a vision for London's future that includes industry and that local authorities can work towards. At present the system of 'managed release' of industrial land does not provide a signal to the market that industry is supported in the city as an integral part of the city fabric. More specifically, it causes confusion for local authority planners and the hierarchical categories of industrial land give the impression that the protection of some businesses is more important 
than others, and support the loss of smaller pockets of space that are integrated into the city fabric, whilst consolidating what is left into larger industrial 'estates'. It also fuels speculation.

Achieving such strategic direction will not be easy, however. We need to first understand why such leadership has been lacking in London and what it would take to change the current direction. Nor can we assume that there is a consensus about how industry could practically be accommodated within the urban fabric, even if there were such political commitment. In the final section, we grappled with the divisive question of whether or not the continued separation of industrial land is desirable. Divergent opinions were revealed on important questions such as how to best facilitate agglomeration, how to create flexibility and how to promote sustainable patterns of land use. We suggest that further research is required if we are to achieve any sort of consensus on these matters. First, we need to better understand the linkages between manufacturers, their suppliers, service industries, customers and workers, so that we better understand how to create agglomeration economies ${ }^{\text {vii }}$. Second, we need to better understand the potential of new urban manufacturing and its geographical manifestations. Third, and finally, we should further explore the impacts on land values of introducing residential land use into industrial areas, as well as solutions for protecting land values within a mixed-use context, with a view to reforming the planning system to facilitate this.

In the meantime, intense pressures on land use in the city and the need to build more housing mean that there is immediate merit in exploring whether it is possible, through clever urban design, to accommodate businesses currently occupying industrial land within a higher density mixed use context. Such optimism is prevalent and its potential should be explored, particularly as many industries become cleaner and quieter with improved technology, and we have little political alternative but to accommodate more housing in our city. Limitations need to also be acknowledged, however. There are still many industrial processes that are genuinely incompatible with housing and we therefore need to retain existing industrial sites that are separated from housing, as well as create new industrial capacity in a mixed use context. Moving forward, we need a better understanding of the spatial requirements of different types of industry and the realistic scope for achieving more mixing of land uses. It also needs to be recognised that, to date, employment-led mixed use has been notoriously difficult to achieve and negotiate. All too often, mixing production and other uses has been used as cover for wholly residential redevelopment, or mixed use schemes with office rather than industrial commercial components. This is due to a lack of political commitment, an over-reliance on planning 
policy, with little leadership or engagement with developers and landowners. London could lead on a series of experimentation projects that aim to integrate industry within a mixed use context through (for example) the specification of design standards to ensure that the space provided effectively meets the needs of industrial occupiers. This could help overcome the risk that inadequate floor-to-ceiling heights, fit outs, servicing arrangements and noise mitigation measures make premises intended for industry unsuitable for these activities in practice. While such design solutions can be imagined, this would not address the question of land values in a mixed use context. Other measures would be required to ensure the affordability of such space for its intended occupiers (see Ferm, 2014 for a discussion of the provision of affordable workspace within a mixed use context). A strong political figure, such as the Mayor of London, could provide the coordination and leadership required to coordinate and bring together the skills required to arrive at workable solutions.

While mixed use redevelopment incorporating industry might provide a future 'fix' to these thorny issues, the loss of industrial land through redevelopment threatens the viability of London's businesses today. Policies need to place greater value on existing productive activities, as well as other businesses in the value chain and pay due regard to benefits of retaining these activities when formulating plans and considering redevelopment proposals. Planning authorities play a crucial role in shaping real estate markets, and ambiguous or unclear wording of policies and site allocations can inflate hopes for residential redevelopment this has knock on effects for existing businesses who might face lease problems or even eviction as a result.

This clearly has a detrimental impact on firms and the wider economy. To embrace London as a city with industry, policymakers need to investigate tools outside the statutory planning system. Public authorities need to take a holistic view, considering (for example) their ownership of land and premises, their role in the procurement of goods and services, and the potential offered by incorporating industry in regeneration strategies.

This paper does not provide any definitive answers as to how we should plan for a industry in our cities, but it has made an argument for the importance of doing so, highlights the challenges faced and sets out a research agenda for achieving better solutions. The discussion in this paper will be directly relevant to other cities in advanced economies that are experiencing population growth and displacement of existing industrial uses, but it should also help inform discussion in a broader set of cities about future land use integration and its challenges. 
1

2

3

4

5

6

7

8

9

10

11

12

13

14

15

16

17

18

19

20

21

22

23

24

25

26

27

28

29

30

31

32

33

34

35

36

37

38

39

40

41

42

43

44

45

46

47

48

49

50

51

52

53

54

55

56

57

58

59

60

\section{Acknowledgements}

We wish to thank the Bartlett School of Planning for providing the seedcorn funding to support this project. No additional specific grant from any funding agency in the public, commercial, or not-for-profit sectors was provided. Inspiration and valuable contributions, which have informed this paper either directly or indirectly, have come from members of Just Space Economy and Planning (in particular Elena Besussi, Mark Brearley, Eileen Conn, Michael Edwards, Myfanwy Taylor and Roy Tindle), Professor Mike Raco, and a seminar on the Productive City organised by Mark Brearley at CASS Cities with European colleagues Jan Zaman and Joachim Declerck (April 2015). A previous version of this paper was presented at the Antwerp Workshop on Reworking the Productive City, part of the ISOCARP conference 2015. 


\begin{abstract}
References
AECOM (2015) Industrial Land Supply and Economy Study. With DTZ and We Made That. London: Greater London Authority.
\end{abstract}

Anderson, C (2012) Makers: The New Industrial Revolution. London: Random House Business Books

Bronstein, Z (2009). 'Industry and the smart city'. Dissent, 56(3), 27-34

CEC (Commission of the European Communities) (1990) Green Paper on the Urban Environment, COM(90)

218. Brussels: CEC. Accessed 20 July 2015:

http://ec.europa.eu/environment/urban/pdf/com90218final en.pdf

Chapple, K (2014) 'The Highest and Best Use, Urban Industrial Land and Job Creation', Economic

Development Quarterly, DOI: 10.1177/0891242413517134

Charisi, A. (2014) 'Is Tech City's startup ecosystem slowly dying? A spatial insight into the cluster's future'. MSc Dissertation in International Real Estate and Planning, University College London.

Cheshire, P, Nathan, M, Overman, H (2014) Urban Economics and Urban Policy. Cheltenham: Edward Elgar.

Chinitz, B (1961) 'Contrasts in Agglomeration: New York and Pittsburgh'. The American Economic Review, 51(2), 279-289.

Cotter, D (2012) 'Putting Atlanta back to work: Integrating light industry into mixed use urban development'. Georgia Tech Enterprise Innovation Institute. Accessed 17 June 2014: http://stip.gatech.edu/wpcontent/uploads/2012/10/STIP-Dan-Cotter.pdf 
Curran, W (2007). 'From the Frying Pan to the Oven': Gentrification and the Experience of Industrial Displacement in Williamsburg, Brooklyn. Urban Studies, 44(8), 1427-1440.

deMaus, N. (2015) 'As Industry City promises a new Sunset Park, some residents fight to maintain the old one'. City Limits, 27 October 2015. Accessed 22 June 2016: http://citylimits.org/2015/10/27/as-industry-citypromises-a-new-sunset-park-some-residents-fight-to-maintain-the-old-one/

Dempwolf, C (2010) 'An evaluation of recent industrial land use studies: do theory and history make better practice?' Working Paper, accessed 20 November 2014:

http://www.academia.edu/319809/An_Evaluation_of_Recent_Industrial_Land_Use_Studies

Do_Theory_and_History_Matter_In_Practice

DETR (Department of Environment, Transport and the Regions) (2000) Our towns and cities: The future delivering an urban renaissance. London: The Stationary Office

Duranton, G, and Puga, D (2000). Diversity and specialisation in cities: why, where and when does it matter? Urban studies, 37(3), 533-555.

Foord, J (2010) 'Mixed-Use Trade-Offs: How to Live and Work in a Compact City Neighbourhood', Built Environment, 36 (1), 47-62

Hall, P (1962) The industries of London since 1861. London: Hutchinson University Library

Harris, R (2013) Servicing the services and smart sheds. Ramidus Consulting. Accessed 20 June 2014, <http://www.ramidus.co.uk/papers/ramidus-servicing-the-services-and-smart-sheds.pdf>

Jacobs, J (1960) The Economy of Cities. New York: Random House 
Just Space Economy and Planning (JSEP)(2014) Response to consultation on Further Alterations to the London Plan. Accessed 18 June 2014: http://justspacelondon.files.wordpress.com/2014/04/falp-jsepresponse.pdf

Kimball, A (2015) Industry City, New York. Presentation at The Working City: Eindhoven, New York, London. London Festival of Architecture, 18 June 2015, Purcell Room, Southbank Centre, SE1 8XX

Feldman, M and Audretsch, D (1999) 'Innovation in cities: science-based diversity, specialization and localized competition', European Economic Review, 43, pp. 409-429.

Ferm, J (2014) 'Delivering affordable workspace: Perspectives of developers and workspace providers in London.' Progress in Planning, 93, 1-49

GLA (Greater London Authority) (2015) The London Plan: Consolidated with alterations since 2011. Adopted March 2015. Accessed 21 July 2015 at: http://www.london.gov.uk/priorities/planning/london-plan

GLA (2014) The Park Royal atlas: an employment study of London's largest industrial area. Greater London Authority.

GLA Intelligence (2013) Population and employment projections to support the London Infrastructure Plan 2050. Update, November 2013. Accessed 11 November 2015: https://www.london.gov.uk/priorities/businesseconomy/vision-and-strategy/infrastructure-plan-2050

GLA (2012) Land for Industry and Transport: Supplementary Planning Guidance. Adopted September 2012. Accessed 23 July 2015 at: https://www.london.gov.uk/priorities/planning/publications/land-for-industry-andtransport-spg

GLA (2010) The Mayor's economic development strategy for London. Adopted May 2010. Accessed 22 July 2015: https://www.london.gov.uk/priorities/business-economy/publications/economic-development-strategy 
GLA (2008) Industrial capacity: London Plan (consolidated with alterations since 2004) Supplementary Planning Guidance. Adopted March 2008.

GLA Intelligence (2013) Population and employment projections to support the London Infrastructure Plan 2050

Graham, D (2007) 'Identifying urbanization and localization externalities in manufacturing and service industries'. Papers in Regional Science 88, 63-84

Harris, R (2013) Servicing the services and smart sheds. Ramidus Consulting. Accessed 20 June 2014: http://www.ramidus.co.uk/papers/ramidus-servicing-the-services-and-smart-sheds.pdf

Heikkila, E, and Hutton, TA (1986). Toward an evaluative framework for land use policy in industrial districts of the urban core: a qualitative analysis of the exclusionary zoning approach. Urban Studies, 23(1), 47-60.

HC (House of Commons) Debate (2011), Wednesday 23 March 2011, Column 966. Accessed 11 December 2015: http://www.parliament.uk/business/news/2011/march/budget-2011-statement/

Jacobs, J (1961) The Death and Life of Great American Cities. New York: Vintage.

JSEP (Just Space Economy and Planning) (2014) Submission to the Further Alterations to the London Plan. Accessed 20 July 2015: https://justspacelondon.files.wordpress.com/2014/04/falp-jsep-response.pdf

Krugman, $\mathrm{P}$ and Lawrence, R (1993). Trade, jobs, and wages (No. w4478). National Bureau of Economic Research. 
Leber, J (2013) ‘Don't divorce design from manufacturing'. MIT Technology Review, 25 January 2013. Accessed 21 July 2015: http://www.technologyreview.com/news/509306/dont-divorce-design-from-manufacturing/

Leigh, N and Hoelzel, N (2012). Smart growth's blind side: Sustainable cities need productive urban industrial land. Journal of the American Planning Association, 78(1), 87-103.

LB (London Borough) of Brent (2011) Site Specific Allocations. Adopted 2011. Accessed 20.4.15 at: https://brent.gov.uk/localplan

LB Camden (2010) Camden Core Strategy 2010-2025. Adopted November 2010. Accessed 31 May 2011 at: http://www.camden.gov.uk/ccm/content/environment/planning-and-built-environment/developmentplans-and-policies/local-development-framework/local-development-framework-I df.en

LB Lewisham (2013) Site Allocations Local Plan. Adoption version, June 2013. Accessed 20 July 2015: http://www.lewisham.gov.uk/myservices/planning/policy/LDF/site-allocations/Pages/default.aspx LB Waltham Forest (2011) Blackhorse Lane urban design framework. Draft for public consultation, August 2011. Accessed 20 July 2015: http://www.walthamforest.gov.uk/Documents/bl-part1.pdf London Datastore (2015) GLA Employment Projections: London-and-sectors-employment (2015). Available at: http://londondatastore-upload.s3.amazonaws.com/dataset/gla-employment-projections/London-and-sectorsemployment.xlsx [Accessed 17 July 2015].

London First (2015) London 2036: An Agenda for Jobs and Growth. For the London Enterprise Panel.

Madanipour, A (2013) Knowledge Economy and the City: Spaces of Knowledge. Routledge.

Marsh, P (2015) 'London and the New Industrial Revolution'. London Essays, Issue 2, 2015, Centre for London: http://essays.centreforlondon.org/issues/technology/london-and-the-new-industrial-revolution/ 
Marsh, P (2012) The New Industrial Revolution: Consumers, globalization and the end of mass production. Yale University Press.

Mayor of London (2013) 2020 Vision: the greatest city on earth. Ambitions for London by Boris Johnson. Greater London Authority.

McDermid, R. (2016) 'City cracks down on S.F. landlords leasing industrial space for offices'. San Francisco Business Times, 15 March 2016. Accessed 22 June 2016: http://www.bizjournals.com/sanfrancisco/blog/realestate/2016/03/sf-industrial-pdr-maker-space-zoning-crack-down.html

London Development Agency and Mayor of London (2010) The Mayor's economic development strategy for London. May 2010. Greater London Authority.

Moore, R. (2015) 'London: The city that ate itself'. The Observer, 28 June 2015. Accessed 29 June 2016 : https://www.theguardian.com/uk-news/2015/jun/28/london-the-city-that-ate-itself-rowan-moore

PwC (PriceWaterhouseCoopers) (2009) The Future of UK Manufacturing. Accessed 22 July 2015: https://www.pwc.co.uk/assets/pdf/ukmanufacturing-300309.pdf

Raco, M and Tunney, E (2010) 'Visibilities and invisibilities in urban development: small business communities and the London Olympics 2012.' Urban Studies, 47 (10), 2069-2091

Ramidus Consulting (2012) London office policy review 2012. Prepared for the Greater London Authority with Roger Tym \& Partners, September 2012

Robson, D (2015) 'What next for Planning in London? And is superdensity a good thing?'. Summary of the minutes of the London Planning and Development Forum held 29 June 2015. Planning in London, issue 94, 2229, July-September 2015 
Roger Tym and Partners (2011a) London Borough of Camden: Business premises study. London Borough of Camden.

Roger Tym and Partners (2011b) Industrial land demand and release benchmarks in London. Greater London Authority.

BBAB (Back Streets Businesses Advisory Board) (2007) 'Made in San Francisco'. Findings and Recommendations to the Board of Supervisors and the Mayor, December 2007. Accessed 5 July 2016:

http://sfgov.org/sfc/bsbab/index_593_268d.html

Savills (2016) 'Tech success sees Fringe rents draw level with City Core, London'. 14 June 2016. Accessed 29 June 2016: http://www.savills.co.uk/_news/article/72418/204080-0/06/2016/tech-success-sees-fringe-rentsdraw-level-with-city-core--london

Scott, A. J. (2006) 'Creative cities: conceptual issues and policy questions'. Journal of Urban Affairs, 2, 1-17.

Scott, AJ (1982). Locational patterns and dynamics of industrial activity in the modern metropolis. Urban Studies, 19(2), 111-141

Stringer, B. (2014) 'Industrial land - breaking the status quo'. Accessed 11 November 2015: http://www.bpf.org.uk/media/blog-posts/industrial-land-breaking-status-quo

Theseira, M (2014) Trading Places: Maximising London's exports potential. Centre for London.

Tuck, A (2009) 'Make some noise'. Monocle, 25 (3), 66, July/August 09

Urban Design Group (2014) Designed for Business: Creating the Industrious Clty, consultation draft. Accessed 1 June 2014: http://www.udg.org.uk/events/designed-business-creating-industrious-city. 
URS (2010) London Industrial Land Baseline. Greater London Authority.

URS (2007) London industrial land release benchmarks. Greater London Authority.

Wickham, M (2015) Updated employment projections for London by sector and trend-based projections by borough. GLA Economics.

Zukin, S (2010) Naked City: The Death and Life of Authentic Urban Places. Oxford: Oxford University Press.

\footnotetext{
'The GLA estimates that London's population will grow by 37\% by 2050 (GLA Intelligence, 2013)

ii This phrase was coined by Cass Cities, London Metropolitan University, and strongly influenced the headline of Rowan Moore's (2015) article in the Observer "London: the city that ate itself".

iii see William Alonso (1964) for an explanation of bid rent theory as applicable to the urban context.

iv $p .8$, GLA Intelligence (2013).

${ }^{v}$ Summarised in Email communication to Just Space Economy and Planning (JSEP) group list from Mark Brearley, Professor at CASS Cities. Subject: Response to GLA Employment Projections 2013. Date:17 October 2014.

${ }^{v i}$ See http://www.camden.gov.uk/ccm/content/environment/planning-and-builtenvironment/two/placeshaping/twocolumn/community-investment-programme/

vii Researchers and practitioners in London have done some important work here, from which we can draw inspiration. See, for example, UCL's Adaptable Suburbs project, led by Laura Vaughan (see http://www.ucl.ac.uk/adaptablesuburbs), LSE's Ordinary Streets project, led by Suzanne Hall (https://Isecities.net/objects/research-projects/ordinary-streets) and Gort Scott's work on Blackhorse Lane (LB Waltham Forest, 2011).
} 